\title{
Pharmacogenomics of the Cystic Fibrosis Transmembrane Conductance Regulator (CFTR) and the Cystic Fibrosis Drug CPX Using Genome Microarray Analysis
}

\author{
Meera Srivastava, Ofer Eidelman, and Harvey B. Pollard \\ Department of Anatomy and Cell Biology, and Institute for \\ Molecular Medicine, USU School of Medicine, USUHS, Bethesda, \\ Maryland, U.S.A. \\ Accepted September 16, 1999.
}

\begin{abstract}
Background: Cystic fibrosis (CF) is the most common lethal recessive disease affecting children in the U.S. and Europe. For this reason, a number of ongoing attempts are being made to treat the disease either by gene therapy or pharmacotherapy. Several phase 1 gene therapy trials have been completed, and a phase 2 clinical trial with the xanthine drug CPX is in progress. The protein coded by the principal CFTR mutation, $\triangle$ F508-CFTR, fails to traffic efficiently from the endoplasmic reticulum to the plasma membrane, and is the pathogenic basis for the missing cAMP-activated plasma membrane chloride channel. CPX acts by binding to the mutant $\triangle$ F508-CFTR and correcting the trafficking deficit. CPX also activates mutant CFTR channels. The comparative genomics of wild-type and mutant CFTR has not previously been studied. However, we have hypothesized that the gene expression patterns of human cells expressing mutant or wild-type CFTR might differ, and that a drug such as CPX might convert the mutant gene expression pattern into one more characteristic of wild-type CFTR. To the extent that this is true, a pharmacogenomic profile for such corrective drugs might be deduced that could simplify
\end{abstract}

the process of drug discovery for CF.

Materials and Methods: To test this hypothesis we used cDNA microarrays to study global gene expression in human cells permanently transfected with either wild-type or mutant CFTR. We also tested the effects of CPX on global gene expression when incubated with cells expressing either mutant or wild-type CFTR.

Results: Wild-type and mutant $\Delta$ F508-CFTR induce distinct and differential changes in cDNA microarrays, significantly affecting up to $5 \%$ of the total genes in the array. CPX also induces substantial mutation-dependent and -independent changes in gene expression. Some of these changes involve movement of gene expression in mutant cells in a direction resembling expression in wildtype cells.

Conclusions: These data clearly demonstrate that cDNA array analysis of cystic fibrosis cells can yield useful pharmacogenomic information with significant relevance to both gene and pharmacological therapy. We suggest that this approach may provide a paradigm for genome-based surrogate endpoint testing of CF therapeutics prior to human administration.

\section{Introduction}

Pharmacogenomics of genetic diseases is a relatively unexplored but promising field, in which the genetic consequences of effective gene or drug therapy can potentially be assessed at the cellular level in terms of specific patterns of global gene expression $(1,2)$. It is hoped that

Address correspondence and reprint requests to: Dr. Harvey B. Pollard, Department of Anatomy and Cell Biology, USU School of Medicine, USUHS, 4301 Jones Bridge Road, Bethesda, MD 20814, U.S.A. Phone: 301-295-3661; Fax: 301295-2822; E-mail: hpollard@usuhs.mil such patterns could be employed as biologically relevant surrogate endpoints when searching for more effective drugs or genes (3). Cystic fibrosis (CF), the most common lethal autosomal recessive disease affecting the U.S. and European populations (4), is an attractive target for pharmacogenomic studies. It is one of the first diseases for which gene therapy has been attempted $(5,6)$ and various drug therapies are currently being developed $(7,8)$. CF is most frequently associated with a homozygous $\Delta$ F508 mutation in the CFTR gene $(9-11)$, and a single copy of the mutant 
gene is carried by approximately $5 \%$ of the population $(12,13)$.

Among the several potential CF drugs being studied (14), the xanthine drug CPX is presently in phase II clinical trials in CF patients. For that reason, we have focussed our attention in the present paper specifically on CPX. The rationale for administration of CPX to CF patients has been severalfold. First, the drug activates wild-type and mutant $\triangle$ F508-CFTR channels in cells (1520) and planar lipid bilayers (21). In addition, CPX also promotes correction of the intrinsic trafficking defect of the $\Delta$ F508-CFTR molecule in the endoplasmic reticulum (8). The mutant CFTR is misfolded (22), and it has been hypothesized that the interaction of the misfolded protein with CPX results in corrected folding and proper trafficking to the plasma membrane $(8,23)$. However, CFTR is known to interact with numerous other cellular proteins (24-26), and CPX also interacts with classical adenosine receptors (27). It is thus possible that CPX may affect CFTR trafficking and function by additional actions that are not immediately apparent from the simpler in vitro and in vivo experiments. Furthermore, different CFTR mutations have profoundly different disease phenotypes (28), including a propensity to develop gastrointestinal and other cancers (29-36). We have therefore hypothesized that the gene expression patterns of human epithelial cells expressing mutant or wild-type CFTR might differ, and that a drug such as CPX might convert the mutant gene expression pattern into one more characteristic of wild-type CFTR.

To test this hypothesis, we have turned to genomic techniques permitting disease-dependent global quantitative analysis of gene expression (37-48). The data presented here clearly demonstrate that the expression of either wildtype or $\Delta$ F508-CFTR in cells has both common as well as specific differential consequences for global gene expression. We have used these data to identify not only the specific consequences of expressing either wild-type or $\triangle F 508$-CFTR in cells, but also the global genomic consequences of gene transfer, as would occur as a consequence of "gene therapy." In addition, we have identified differential effects of CPX on global gene expression, depending on whether wildtype or mutant CFTR is being expressed. Most importantly, CPX does indeed induce a subset of genes in mutant CFTR cells to move in the direction of expression levels found in wild-type CFTR cells. Furthermore, we have learned that
CPX can induce massive overexpression of certain genes, independently of the mutational form of CFTR concurrently being expressed. The most profound example of this effect is the CPX-dependent overexpression of two protein kinase $A$ (PKA) regulatory subunits, a tyrosine kinase, and several different heat shock proteins. Such responses can be used as diagnostic markers of CPX action, and we therefore believe that this approach to the pharmacogenomics of CPX may provide important, testable insights into CPX action in CF. This approach may also provide a paradigm for genome-based surrogate endpoint testing of $\mathrm{CF}$ drugs prior to human administration.

\section{Materials and Methods}

Cells and Culture Conditions

PERMANENT TRANSFECTION OF HEK293 CELLS BY WILDTYPE AND $\triangle$ F508-CFTR. Wild-type and $\triangle$ F508-CFTR cDNA (6) were subcloned into the eukaryotic expression vector pCEP4 (Invitrogen, San Diego, CA) between the NheI and $X h o I$ restriction sites according to the method of Tao and colleagues (49) to create the recombinant vector pCEP4(CFTR). Following generation of the permanently transfected cell lines, hygromycin was omitted from all subsequent culture conditions.

CULTURE OF CELLS WITH CPX. HEK293 cells, either parental or transfected with either wild-type or $\triangle$ F508 CFTR, were split 1:10 and grown to confluence in $100 \mathrm{~cm}^{2}$ tissue culture dishes in Dulbecco's modified Eagle's medium (DMEM), supplemented with $10 \%$ fetal calf serum (FCS) and $1 \%$ glutamine. CPX was prepared as a $10-\mathrm{mM}$ stock solution in DMSO, and after reaching cell confluence the medium was replaced with either fresh medium containing $0.1 \%$ dimethylsulfoxide (DMSO) (control) or medium with $0.1 \%$ DMSO and $20 \mu \mathrm{M}$ CPX. The cells were then incubated as indicated for either $24 \mathrm{hr}$ or $48 \mathrm{hr}$ with CPX. In a different experiment, cells were incubated for $24 \mathrm{hr}$ with CPX and then moved back to control medium for an additional $24 \mathrm{hr}$ to study the consequences of drug washout. At the end of the incubation period, the medium was completely aspirated and the flasks frozen at $-20^{\circ} \mathrm{C}$, awaiting RNA extraction. 


\section{cDNA Array Technology}

PREPARATION AND LABELING OF RNA. Total RNA was prepared by the method of Chirgwin et al. (50) from HEK293 cells, wild-type-transfected HEK293 cells, and $\Delta$ F508-CFTR-transfected HEK293 cells, with and without CPX. The total RNA was then subjected to DNAse 1 digestion to eliminate genomic DNA contamination. Subsequently, two rounds of purification of poly $\mathrm{A}+$ RNA from total RNA was performed using the mRNA isolation kit from Invitrogen (Carlsbad, CA) as recommended by the manufacturer. The quality of the RNA was tested by running a formaldehyde-denatured agarose gel and quantitated by measuring the optical density at $260 \mathrm{~nm} .{ }^{32} \mathrm{P}$ labeled cDNA probes were synthesized from $1 \mu \mathrm{g}$ of poly A+ RNA from each sample using MMLV reverse transcriptase, dNTP mix, and the cDNA synthesis (CDS) primer mix comprising the oligonucleotide sequences for the $\mathbf{5 8 8}$ genes spotted on the human Atlas ${ }^{\circledR}$ cDNA array (Clonetech, Carlsbad, CA). The reaction was carried out in a thermocycler set at $50^{\circ} \mathrm{C}$ for $25 \mathrm{~min}$ and terminated by the addition of $0.1 \mathrm{M}$ EDTA, $\mathrm{pH}$ 8.0 , and $1 \mathrm{mg} / \mathrm{ml}$ glycogen. The ${ }^{32} \mathrm{P}$-labeled cDNA probes were purified from unincorporated ${ }^{32}$ P-labeled nucleotides by using a CHROMA SPIN-200 column (Clonetech, Palo Alto, CA), as recommended by the manufacturer. The human Atlas cDNA expression array was prehybridized using Express Hyb (Clonetech) at $68^{\circ} \mathrm{C}$ for $\mathrm{l} \mathrm{hr}$ and hybridized overnight at $68^{\circ} \mathrm{C}$ with the denatured and neutralized ${ }^{32} \mathrm{P}$-labeled cDNA probes. The membrane was washed three times with $2 \times$ sodium chloride and sodium citrate (SSC), $1 \%$ SDS at $68^{\circ} \mathrm{C}$ for $30 \mathrm{~min}$ each, and twice with $0.1 \%$ SSC, $0.5 \%$ SDS at $68^{\circ} \mathrm{C}$ for 30 min each. The Atlas array was then exposed overnight to $\mathrm{X}$-ray film or for $6 \mathrm{hr}$ to a Storm PhosphorImager (Molecular Dynamics, Sunnyvale, CA) plate. All data shown here were derived solely from the first use of each microarray blot.

IMAGING AND QUANTITATION OF THE CDNA ARRAY. Atlas cDNA array blots were assayed on a Storm PhosphorImager using proprietary PhosphorImager screens. Each blot was exposed for $6 \mathrm{hr}$. The intensity of each grid point, at a resolution of 200 $\mu \mathrm{m}$, was quantified, including the ubiquitin standard and the blanks. The intensity data were then loaded into a Microsoft Excell spreadsheet. To determine the absolute density, each grid point was corrected by subtraction of the background and divided by the intensity of the ubiq- uitin gene, a standard stable housekeeping gene present on each blot. Thus each data point, in duplicate, could be compared quantitatively to identical points on duplicate blots. Accuracy of identical samples on duplicate cDNA targets on the same blot was $\sim 1.3 \%$. The average interblot accuracy for independently prepared duplicate samples on duplicate cDNA targets was estimated to be at least $12 \%$. Statistically significant changes were in excess of these errors. To further validate the analysis, the data were also independently evaluated using the PSCAN program for point identification and the JMP program for graphical organization as described by Munson and colleagues (http://abs.cit.nih.gov). Each experiment was assayed at least in duplicate, as indicated.

DATA MINING USING THE GENE RATIO ANALYSIS PARADIGM (GRASP). The analysis of the effects of a specific CFTR mutation on global gene expression is performed as follows. Orthogonal graphs are prepared by plotting the ratios of specific gene expression in $\triangle \mathrm{F} 508$-CFTR-transfected cells to expression in parental cells on the vertical axis against the equivalent ratio for the same gene in wild-type CFTR-expressing cells on the horizontal axis (see Fig. 2a for an example). For each graph, we calculate the averages and the standard deviations of the distribution of the logarithms of the individually measured gene expression ratios on the horizontal and vertical axes. We also perform this calculation for the differences between the logs of each pair of ratios of all genes (see Figs. 2b-d for examples). The criterion of being more than 1 standard deviation ( 1 $\mathrm{SD})$ away from the respective average is chosen as an index of those genes in parental cells whose expression levels had been changed by the transfection of either wild-type or $\triangle$ F508-CFTR. We use a 2 SD criterion for determining that a change is significant. The SD values are calculated separately for expression ratios between wild-type or mutant cells relative to parental cells, or for differences in expression level ratios between wild-type and mutant cells. Using the SD as a discriminator in this way is one of several novel contributions of the GRASP approach to mining gene expression data. Note that the genes whose relative expression levels occur on the diagonal are those genes whose expression levels are mutation independent, or are simply related to transfection, per se.

The second step in the GRASP data mining approach is to represent the effects of drugs or 
genes as a vector in genomic space. We define here a genomic vector as originating on the location specified by the gene's expression levels in the absence of drug, and terminating at the location specified by the gene's expression levels in the presence of the drug. The length of this genomic vector is a measure of the efficacy of the drug's effect on the expression of that particular gene. The angle is related to the differential effect of the drug depending on the mutational state of CFTR. For example, the vectors of those genes for which the effects of CPX on their expression level are not specifically dependent on the CFTR mutation state have angles close to the main diagonal (i.e., $\sim 45^{\circ}$ in the positive direction or $\sim 225^{\circ}$ in the negative direction). Conversely, the vectors for the genes whose expression is significantly dependent on the mutational status of CFTR are sorted to the 2nd quadrant $(90 \leq$ $\left.\theta \leq 180^{\circ}\right)$ or to the 4th quadrant $\left(270 \leq \theta \leq 0^{\circ}\right)$. Vector lengths can be discriminated by their number of SDs from the average length (see Fig. 4 for an application). We emphasize here that in order to prepare these vectors, a common basis for comparison is needed for mutant and wild-type CFTR expressing cells, with or without CPX. Expression by the parental cell line is thus the only common basis available.

\section{Results}

\section{Differential Effects of Recombinant Wild-Type CFTR and $\triangle F 508-C F T R$ on Global Gene Expression in HEK293 Cells}

The molecular consequences of wild-type or $\Delta$ F508-CFTR genes for global gene expression in a human epithelial cell line are shown in Figure 1. This figure shows a comparison among cDNA arrays of parental cells (Fig. la), transfected with either wild-type CFTR (Fig. lb) or $\triangle$ F508-CFTR (Fig. 1c). Using a statistically weighted graphical inspection approach, we have been able to detect those genes whose expression levels change specifically and significantly upon transfection of either wild-type CFTR or $\triangle$ F508-CFTR, and to sort them quantitatively from those genes whose expression levels remain essentially the same as in the parental cell controls.

The results of this search are shown in Figure $2 \mathrm{a}$, in which ratios of expression levels of all 588 mRNAs are plotted using respective data from all three cell types. In the figure, the horizontal axis is the ratio of expression levels of

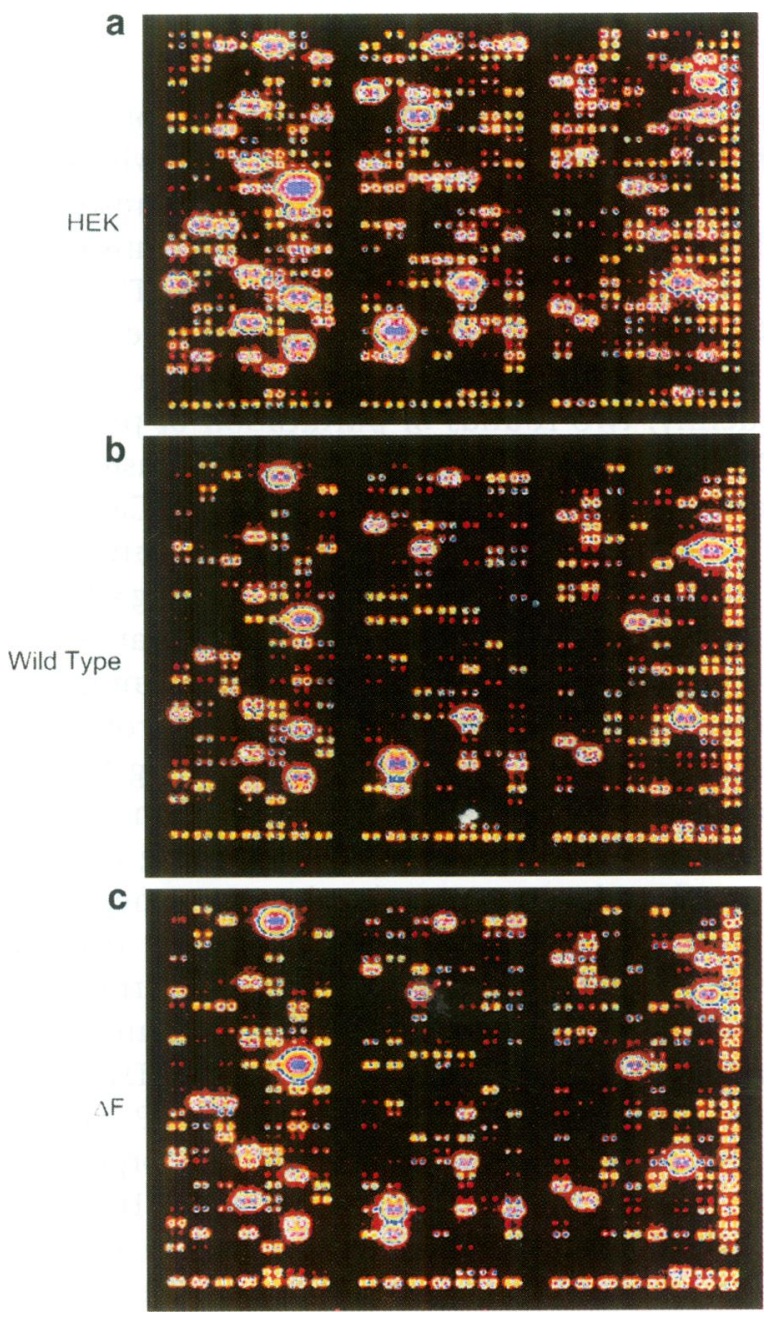

Fig. 1. cDNA array analysis of wild-type and $\triangle$ F508-CFTR transfected HEK293 cells. (a) cDNA array of mRNA from parental HEK293 cells, used to derive wild-type and $\Delta$ F508-CFTR-transfected cells in $b$ and c. (b) cDNA array of mRNA from HEK293 cells transfected with wild-type CFTR. (c) cDNA array of mRNA from HEK293 cells transfected with $\triangle$ F508-CFTR.

given genes in wild-type CFTR-transfected cells relative to parental cells alone. The vertical axis in this figure is the ratio of expression of the same genes in $\Delta$ F508-CFTR-transfected cells relative to parental cells alone. As described in Materials and Methods, SDs have been calculated from the distributions of ratios of gene expression. Histograms of these ratios are explicitly shown for wild-type CFTR relative to parental cells (Fig. 2b), $\triangle$ F508-CFTR relative to parental cells (Fig. 2c), and $\Delta$ F508-CFTR relative to wildtype CFTR cells (Fig. $2 \mathrm{~d}$ ).

The first step in this data-sieving operation is to eliminate all genes whose expression ratios differ from 1.0 by $<1$ SD in both transfected cells. 


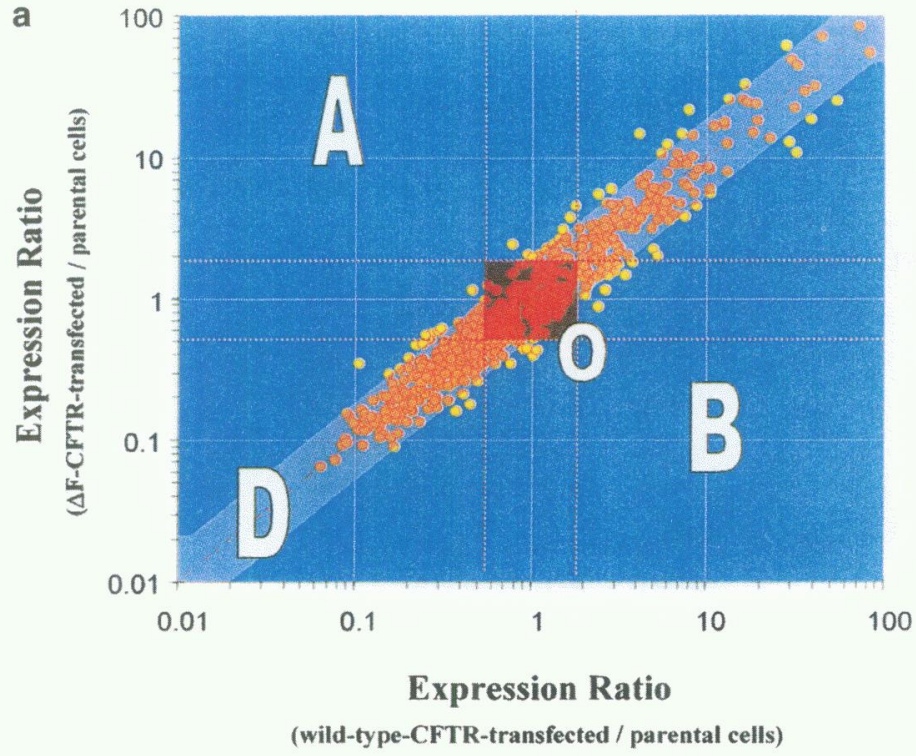

Fig. 2. Effect of a functional mutation in CFTR on global gene expression. (a) Analysis of the complete cDNA arrays for cells expressing mutant and wild-type CFTR. The horizontal axis is the ratio of expression of specific genes in wild-type CFTR-transfected cells to parental cells alone. The vertical axis is the ratio of expression of specific genes in $\Delta$ F508-CFTR-transfected cells to parental cells alone. Vertical and horizontal dotted lines represent $1 \mathrm{SD}$ around the respective averages, calculated from data in b and c, below. $\mathrm{D}$, genes on the diagonal. The solid box $(\mathrm{O})$ in $\mathrm{D}$ marks genes that are not significantly different (i.e., $<1$ SD) between wild-type and $\Delta$ F508CFTR cells. A, genes above the diagonal in which the expression level in $\triangle$ F508-CFTR cells is significantly higher than in wild-type CFTR cells. B, genes below the diagonal in which the expression level in wild-type CFTR cells is significantly higher than in $\Delta$ F508-CFTR cells. Genes in the middle square $(\mathrm{O})$ are those whose expressions are the same in all three cell types. (b) Histogram of ratios of gene expression for wild-type CFTR-transfected cells relative to parental cells. (c) Histogram of ratios of gene expression for $\Delta$ F508-CFTR cells relative to parental cells. (d) Histogram of ratios of gene expression for $\Delta$ F508-CFTR cells relative to wild-type CFTR-transfected cells. b
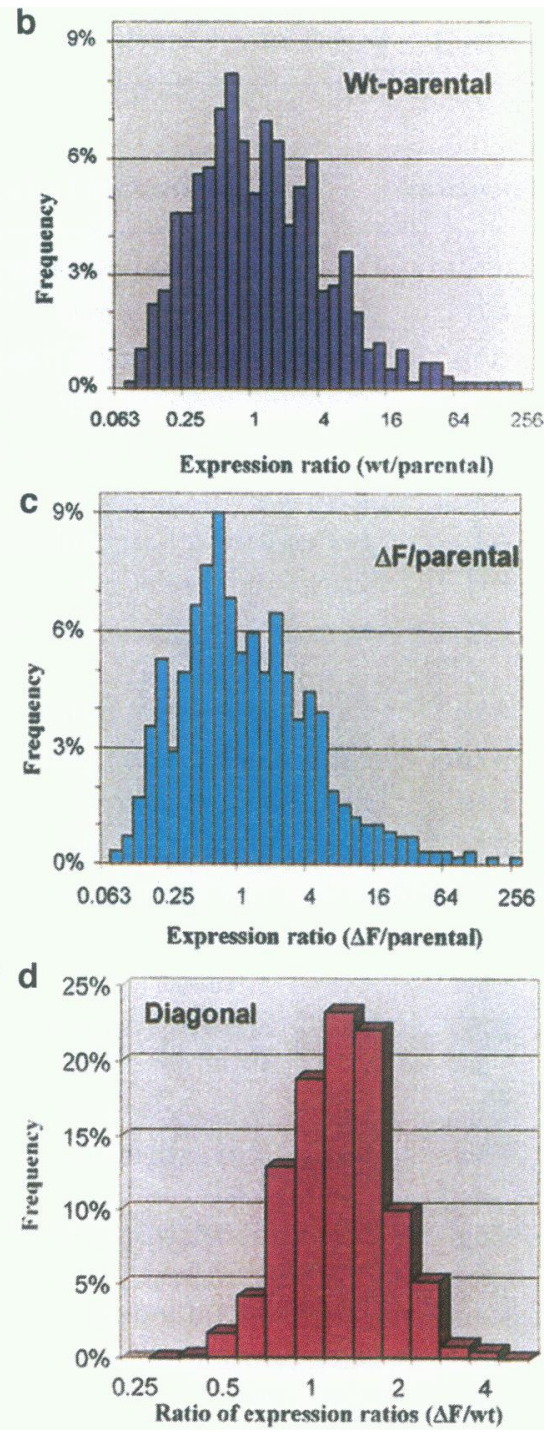

The genes in this category are shown in the center box $\mathrm{O}$ of Figure 2a. Their removal results in the elimination of $340(58 \%)$ of total genes in the array. The interpretation to be placed on these genes is that they are not significantly affected by either the transfection process or by the mutational state of CFTR. However, importantly, the remaining 248 genes ( $42 \%$ of the total) are affected by our experimental interventions, and it is therefore necessary to distinguish between the two root causes of expression variation.

To this end, we start by finding those genes whose expression is unaffected by the mutational state of CFTR. These genes have expression ratios for wild-type or mutant CFTR that differ by $<1$ SD from each other, and reside along the diagonal, D, in Figure 2a. These genes sense the fact of transfection but are not affected by the mutational and/or functional state of CFTR. This results in the elimination of an additional 153 genes $(26 \%)$. The remaining 95 genes $(16 \%)$ are those whose expression levels change by $>1$ SD because of the mutational status of CFTR. These latter genes belong to two classes, distinguished by whether they are above (A) or below (B) the diagonal (D). We can discriminate even further within this group by selecting a subset of 26 genes $(4.3 \%)$ whose expression is significantly changed by $>2$ SDs from the norm (see Table 1).

The classes of differences among these remaining 26 genes can be distinguished on the basis of which domain of the graph the differences are found (viz., A or B), and how close a gene is to one axis relative to another. For example, of these 26 genes, 12 are in the vi- 
Table 1. Effect of a functional mutation in CFTR on global gene expression

\begin{tabular}{|c|c|c|c|c|c|c|c|}
\hline \multirow[b]{2}{*}{ Location } & \multirow[b]{2}{*}{ Name of Gene } & \multicolumn{3}{|c|}{ Expression Level $^{a}$} & \multirow[b]{2}{*}{ Significance } & \multirow[b]{2}{*}{$\mathbf{S}$} & \multirow{2}{*}{$\begin{array}{c}\text { Gene-Bank } \\
\text { Accession } \\
\text { No. }\end{array}$} \\
\hline & & HEK & wt & $\mathbf{\Delta F}$ & & & \\
\hline \multicolumn{8}{|c|}{ Close to the y-axis ( $\Delta \mathrm{F}$ changes while wt $\sim$ parental) } \\
\hline E2n & Interleukin-6 receptor & 0.74 & 0.77 & 2.42 & $* \star *$ & 3.0 & M20566 \\
\hline $\mathrm{D} 3 \mathrm{~b}$ & DNA binding protein (DBl) & 10.79 & 7.96 & 21.58 & $* *$ & 2.6 & D28118 \\
\hline $\mathrm{E} 3 \mathrm{~m}$ & Cytokine receptor (EB13) & 0.60 & 0.46 & 1.16 & ** & 2.5 & L08187 \\
\hline A7l & Cell cycle control protein (C-1) & 1.59 & 1.65 & 3.77 & ** & 2.2 & U41816 \\
\hline $\mathrm{D} 4 \mathrm{j}$ & DNA-binding protein (NF-El) & 27.40 & 28.05 & 60.83 & ** & 2.1 & M76541 \\
\hline $\mathrm{A} 4 \mathrm{c}$ & Breast cancer susceptibility (BRCA2) & 0.43 & 0.57 & 1.22 & ** & 2.0 & U43746 \\
\hline Elj & PDGF-alpha receptor & 1.98 & 2.43 & 0.88 & ** & 2.7 & M21574 \\
\hline E5f & $\begin{array}{l}\text { Lymphocyte activation antigen } \\
\text { CD } 30\end{array}$ & 3.96 & 5.32 & 2.03 & ** & 2.6 & M83554 \\
\hline A7e & Cell cycle control protein Tob & 1.43 & 1.02 & 0.39 & ** & 2.5 & D38305 \\
\hline B7m & Heat shock protein (HSP 70) & 0.47 & 0.37 & 0.16 & ** & 2.3 & M11717 \\
\hline Elk & PDGF-beta receptor & 5.95 & 5.04 & 2.22 & ** & 2.2 & M21616 \\
\hline E7n & Semaphorin (CD100) & 1.33 & 0.96 & 0.44 & ** & 2.1 & U60800 \\
\hline \multicolumn{8}{|c|}{ Close to the $\mathrm{x}$-axis (wt changes while $\Delta \mathrm{F} \sim$ parental) } \\
\hline E3n & Interleukin 12 receptor component & 0.26 & 0.11 & 0.34 & $* * *$ & 3.1 & U03187 \\
\hline D7a & GATA-3 transcription factor & 3.92 & 1.81 & 4.59 & ** & 2.5 & X55122 \\
\hline $\mathrm{E} 2 \mathrm{j}$ & $\begin{array}{l}\text { NGFR-related B-lymphocyte } \\
\text { activation molecule }\end{array}$ & 14.21 & 32.25 & 11.00 & ** & 2.9 & $\mathrm{X} 60592$ \\
\hline $\mathrm{F} 4 \mathrm{e}$ & Connective tissue growth factor & 0.27 & 0.45 & 0.18 & ** & 2.5 & M92934 \\
\hline F5d & $\begin{array}{l}\text { Neutrophil-activating peptide } \\
\text { ENA-78 }\end{array}$ & 0.58 & 1.08 & 0.43 & ** & 2.5 & X78686 \\
\hline C6g & $\begin{array}{l}\text { Replication factor C } 40-\mathrm{kDa} \text { subunit } \\
\text { (A1) }\end{array}$ & 0.71 & 2.64 & 1.15 & ** & 2.2 & M87338 \\
\hline \multicolumn{8}{|c|}{ Distant from both $\mathrm{x}$ - and $\mathrm{y}$-axes } \\
\hline A5c & AXL tyrosine kinase receptor & 1.52 & 4.16 & 14.67 & $* * *$ & 3.3 & M76125 \\
\hline A6j & Cyclin $\mathrm{H}$ & 1.18 & 2.41 & 5.52 & $* *$ & 2.2 & U11791 \\
\hline $\mathrm{C} 6 \mathrm{c}$ & $\begin{array}{l}\text { ATP-dependent DNA helicase II } \\
70-\mathrm{kDa} \text { subunit }\end{array}$ & 0.57 & 0.95 & 2.07 & ** & 2.1 & M32865 \\
\hline $\mathrm{F} 4 \mathrm{a}$ & Growth/differentiation factor GDF-1 & 0.37 & 0.26 & 0.55 & ** & 2.0 & M62302 \\
\hline D6i & $\begin{array}{l}\text { HOX Al homeodomain protein } \\
\text { (HOXAl) }\end{array}$ & 2.50 & 3.43 & 1.45 & ** & 2.3 & $\mathrm{U} 10421$ \\
\hline D61 & DNA binding protein (ard-1) & 37.06 & 54.18 & 25.42 & ** & 2.0 & U14575 \\
\hline Blf & Coagulating factor II receptor & 18.55 & 29.24 & 13.01 & ** & 2.1 & M62424 \\
\hline F7n & Beta-preprotachykinin & 0.59 & 0.76 & 0.34 & ** & 2.1 & X54469 \\
\hline
\end{tabular}

HEK, HEK-293, human embryonic kidney cell line; wt, wild type; S, standard deviation.

${ }^{a}$ Relative to average expression level of all 588 genes.

cinity of the $y$ - (vertical) axis. These genes in the vicinity of the $y$-axis are located in the space enclosed between the positive $y$-axis, \pm 1 $S D$, and above the \pm 1 SD diagonal; and in the space enclosed between the negative $y$-axis, $\pm 1 \mathrm{SD}$, and the $\pm 1 \mathrm{SD}$ diagonal, but below the
1 SD line on the $\mathrm{x}$-axis. These 12 genes are preferentially expressed in $\Delta$ F508-CFTR cells. However, in wild-type CFTR cells, their expression levels are not significantly different from expression of these same genes in the parental cells. Thus these genes would appear 


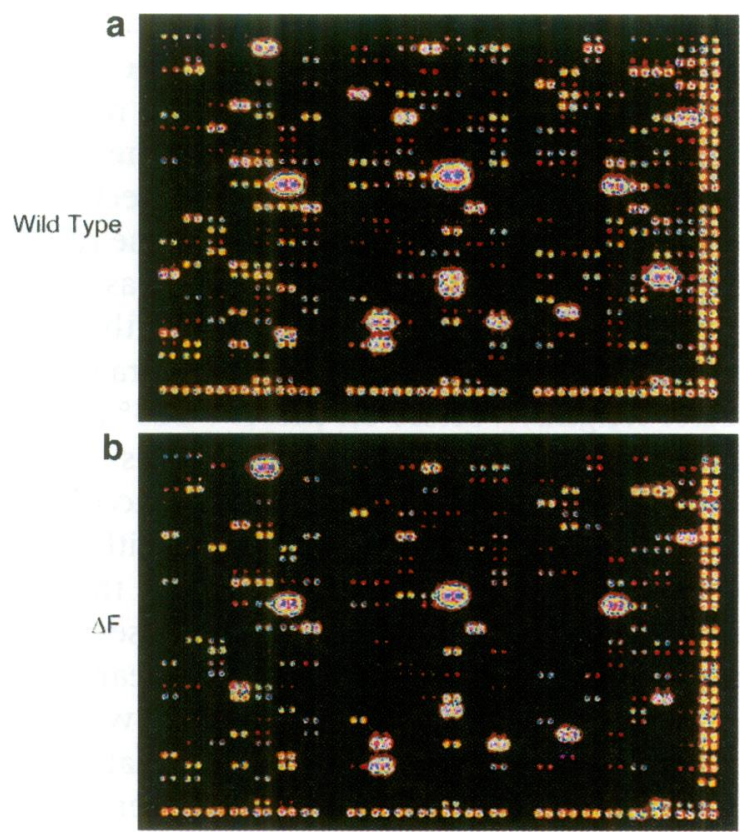

Fig. 3. cDNA array analysis of wild-type and $\triangle$ F508-CFTR cells treated with CPX. (a) CDNA array of mRNA from wild-type CFTR cells treated with $20 \mu \mathrm{M}$ CPX. (b) cDNA array of mRNA from $\Delta$ F508-CFTR cells treated with $20 \mu \mathrm{M}$ CPX.

to be reporting on the consequences for them of a dysfunctional $\Delta$ F508-CFTR. Six of the 26 genes are in the vicinity of the $\mathrm{x}$ - (horizontal) axis. These genes are preferentially expressed in wild-type CFTR cells. However, in $\triangle$ F508CFTR cells, their expression levels are not significantly different from expression of these same genes in the parental cells. Thus these genes would appear to be reporting on consequences for them of having a functional wildtype CFTR in the cell. Finally, eight genes are away from both axes and outside the 2 standard deviation limit from the diagonal. Expression of these latter genes are differentially affected by both wild-type and mutant CFTR. The names and classification of these genes are given in Table 1 . At the simplest level of interpretation, these data mean that "gene therapy" with wild-type CFTR makes a difference for many more genes than just CFTR, and that the mutational state of the transfected CFTR has its own specific consequences for global gene expression.

Effects of CPX on Global Gene Expression by Cells Expressing Either Wild-Type or $\triangle F 508$-CFTR

CPX was administered for $48 \mathrm{hr}$ to both $\triangle \mathrm{F} 508$ and wild-type CFTR-transfected cells, and analytic

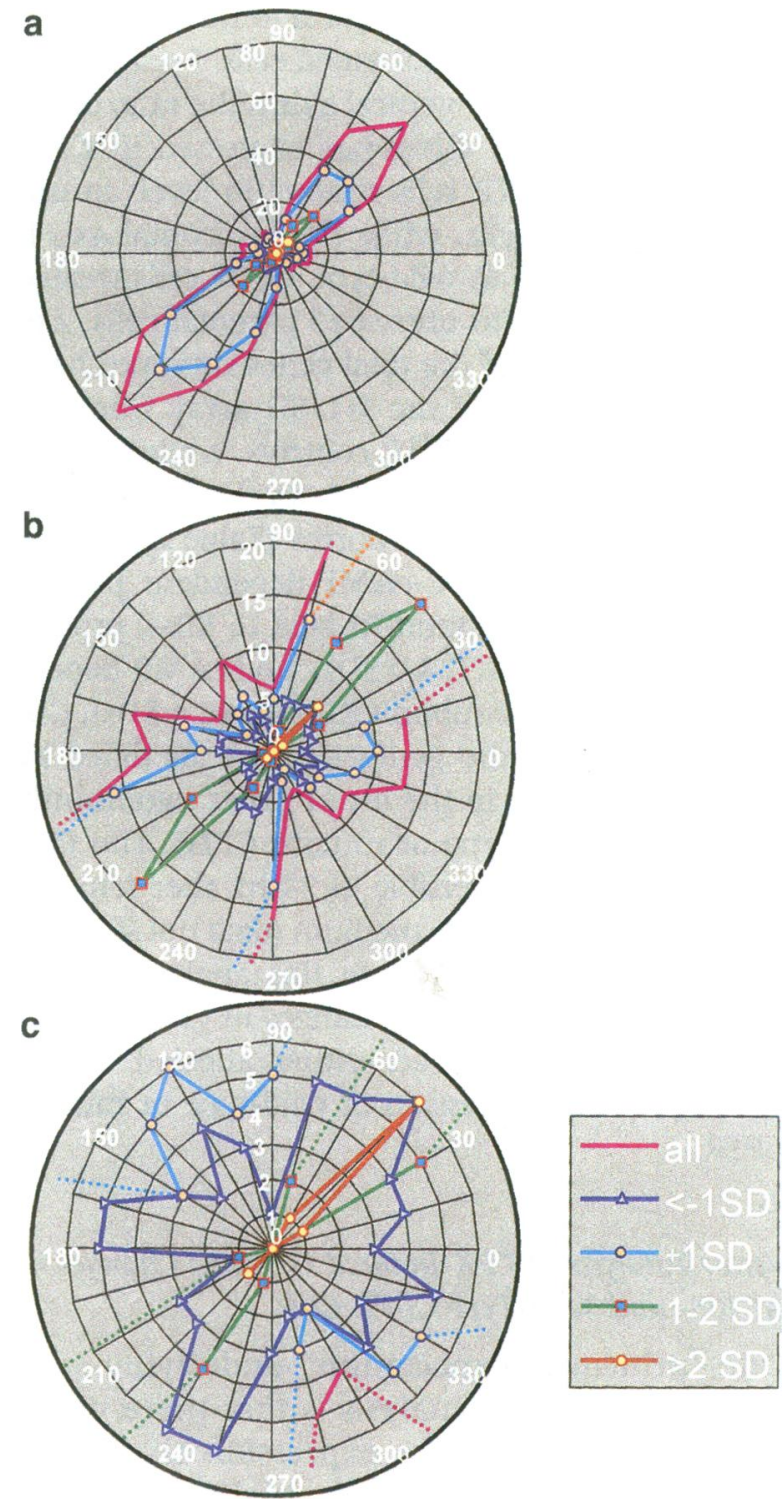

Fig. 4. Radial histogram of the effect of CPX on global gene expression of wild-type and $\triangle F 508$ CFTR-transfected cells. (a) Low-resolution radial distribution plot of CPX induced changes in gene expression. Angles are directions in orthogonal genomic space in which ratios of gene expression were changed by exposure to CPX. The radius represents numbers of genes in that category. The colors represent all genes (red); genes whose vector length is changed by $<1 \mathrm{SD}$ from the average (blue); genes whose vector length is changed by 1 SD from the average (yellow); genes whose vector length is changed by $1-2$ SDs (green); and those changed by more than 2 SDs (brown). (b) Higher-resolution radial distribution plot of CPX-induced changes in gene expression. (c) Highest-resolution radial distribution plot of CPX-induced changes in gene expression.

cDNA microarrays were prepared (Fig. 3a,b). Even by eye, substantial, differential changes can be seen. A quantitative analysis of these data was then 
performed in a manner identical to that developed in Figure 2 to analyze untreated cells. For the new plot (not shown), the vertical axis is the ratio of the expression level of the genes expressed in CPXtreated $\triangle$ F508-CFTR cells relative to levels in untreated parental cells, while the horizontal axis is the ratio of levels in wild-type CFTR cells treated with CPX relative to untreated parental cells. Approximately $10 \%$ of the total genes surveyed have expression levels that are $>1$ SD away from the $\Delta$ F508- or wild-type CFTR controls, while only 28 genes $(4.8 \%)$ are expressed at levels of 2 or more SDs from their respective norms (Table 2). Prominent among these are cAMP-dependent protein kinase regulatory subunit RI-beta (6 SDs), protein tyrosine kinase (JAK1, 4.9 SDs), and cAMP-dependent protein kinase subunit RII-beta (2.4 SDs). Curiously, many of the genes that are modified by CPX fail to appear in the list of genes significantly modified by wild-type or mutant CFTR. The CPX effect is virtually reversible in $24 \mathrm{hr}$ after removal of CPX from the culture medium (data not shown). A principal conclusion from this analysis is that CPX can elicit substantial changes in gene expression from genes that are either affected or not affected by the expression of wild-type or mutant CFTR.

Vector Analysis of CPX-Induced Genomic Changes in $\triangle$ F508- and Wild-Type CFTR Cells

One principal expectation underlying this pharmacogenomic analysis is that there might exist a pattern of gene expression that could signal whether a given drug might be a therapeutic candidate. At the simplest level, one might ask what genes were caused by CPX to move from an "aberrant" expression level in $\Delta$ F508-CFTR cells to one more characteristic of that gene's expression in wild-type CFTR cells. Logically, a set of such genomic markers might be useful in predicting whether a specific drug might be of therapeutic use; conversely, the possibility of unwanted side effects might also be discerned. To test this hypothesis, our strategy has been to view graphs such as that shown in Figure 2a as "genomic space," before and after CPX treatment, respectively. This allows the construction of a drug-related "difference vector" between the location of the data point in the absence of CPX and the location in the presence of CPX (see Materials and Methods for more details).

A low-resolution radial histogram of the angular distribution of these difference vectors is shown in Figure 4a. The labels on the circumference of the circle represent the angles of the vectors from the horizontal axis. The radius of the circle represents the numbers of genes at that angle. The given angle is that direction in genomic space (see Fig. 2) into which the relative gene expression moved when CPX was added. The colors delineate genes whose lengths are at different SDs from the logarithmic average of all vector lengths. Vectors on the $45^{\circ}-225^{\circ}$ axis are those genes whose expression levels change equally, positively, or negatively, on account of the effect of CPX on cells expressing either mutant or wild-type CFTR. For example, the gene for the cAMP-dependent protein kinase regulatory subunit RII-beta (see Table 2 ) appears at the $45^{\circ}$ angle because both mutant and wild-type CFTR cells responded equally and dramatically to CPX by increased expression of that gene. Gene vectors on the $45^{\circ}-225^{\circ}$ axis are thus sorted by definition into the 1 st quadrant $\left(0^{\circ}<\theta<90^{\circ}\right)$ or 3rd quadrant $\left(180<\theta<270^{\circ}\right)$, respectively. Genes with the longest drug vectors (viz., 1-2 or $>2$ SD) are almost entirely along the $45^{\circ}-225^{\circ}$ axis, while those with drug vector lengths $<1 \mathrm{SD}$ are distributed randomly about the center (see Fig. 4c, blue line). The latter vectors represent the noise in the system.

By contrast, the higher-resolution histograms (see Fig. $4 \mathrm{~b}, \mathrm{c}$ ) show smaller numbers of vectors whose angles fall into the 2 nd quadrant $\left(90 \leq \theta \leq 180^{\circ}\right)$ or the 4 th quadrant $(270 \leq \theta \leq$ $\left.0^{\circ}\right)$. The importance of a gene vector being sorted into the 2 nd or 4 th quadrant is that these are the genes whose response to CPX is mutation dependent. The distribution of vectors of average length (i.e., those that are within I SD of the logarithmic mean) are colored cyan in the histogram, and show a significant population in the 2nd and 4th quadrants. This population consists of 69 genes $(12 \%)$. As an alternative to simply listing all 69 , we have selected a subset of these genes (see Table 3 ) that have been shown above to be changed significantly ( $\geq 2$ SDs) by either mutation or CPX.

As shown in Table 3, the advantage of data mining using drug vector analysis is that the vector angle allows us to distinguish between CPX effects that are either predominantly on mutant cells, predominantly on wild-type cells, or on both mutant and wild-type cells but in opposite directions. As an example of the latter situation in the 2nd quadrant, changes in the $120^{\circ}-150^{\circ}$ range delineate genes (e.g., BRCA2) in which CPX exposure leads to an expression increment in mutant CFTR cells but a 
Table 2. Effects of CPX on global gene expression in wild-type and $\triangle$ F508-CFTR cells

\begin{tabular}{|c|c|c|c|c|c|c|c|c|}
\hline \multirow[b]{2}{*}{ Location } & \multirow[b]{2}{*}{ Name of Gene } & \multicolumn{7}{|c|}{ Expression Level $^{a}$} \\
\hline & & HEK & wt & $\Delta \mathbf{F}$ & $\begin{array}{l}\text { wt }+ \\
\text { CPX }\end{array}$ & $\begin{array}{l}\mathbf{C P X}+ \\
\mathbf{C P X}\end{array}$ & Significance & $\mathbf{S}$ \\
\hline $\mathrm{B} 5 \mathrm{~m}$ & PKA regulatory subunit RI $\beta$ & 5.78 & 2.44 & 2.56 & 203.3 & 234.8 & $\star * \star$ & 6.0 \\
\hline B5l & Protein-tyrosine kinase (JAKl) & 0.39 & 0.19 & 0.19 & 10.42 & 8.20 & $* * *$ & 4.9 \\
\hline B5n & Extracellular signal-regulated kinase 2 & 2.21 & 1.24 & 0.77 & 18.89 & 27.82 & $* * *$ & 4.7 \\
\hline B6m & MAPKAP kinase (3pK) & 0.40 & 0.18 & 0.11 & 4.16 & 2.42 & $* * *$ & 4.1 \\
\hline B6n & $\begin{array}{l}\text { Receptor tyrosine kinase ligand LERK-3 } \\
\text { (EPLG3) }\end{array}$ & 0.30 & 0.12 & 0.12 & 2.40 & 1.65 & $* * *$ & 3.4 \\
\hline $\mathrm{D} 4 \mathrm{j}$ & DNA-binding protein (NF-El) & 27.40 & 28.05 & 60.83 & 3.75 & 4.64 & $* * *$ & 3.4 \\
\hline $\mathrm{B} 7 \mathrm{k}$ & Heat shock protein hsp86 & 0.31 & 0.17 & 0.19 & 1.76 & 2.41 & $* * *$ & 3.3 \\
\hline E5h & $\begin{array}{l}\text { Intercellular adhesion molecule-1 } \\
\text { (ICAM-1) }\end{array}$ & 4.70 & 3.51 & 3.92 & 34.72 & 42.56 & $* \star *$ & 3.1 \\
\hline B4d & Active transcription factor CREB & 0.61 & 0.29 & 0.29 & 1.31 & 2.57 & ** & 2.9 \\
\hline $\mathrm{D} 3 \mathrm{~b}$ & DB 1 & 10.79 & 7.96 & 21.58 & 2.18 & 2.50 & ** & 2.8 \\
\hline F6b & Interleukin-6 (IL-6) precursor & 1.19 & 0.39 & 0.43 & 5.73 & 3.07 & ** & 2.6 \\
\hline Ala & c-myc oncogene & 0.56 & 0.26 & 0.30 & 1.91 & 2.03 & ** & 2.5 \\
\hline $\mathrm{F} 2 \mathrm{n}$ & $\begin{array}{l}\text { Macrophage inflammatory protein } \\
\text { GOS19-1 }\end{array}$ & 0.09 & 0.07 & 0.07 & 0.39 & 0.43 & ** & 2.5 \\
\hline B5k & $\begin{array}{l}\text { cAMP-dependent protein kinase subunit } \\
\text { RII-beta }\end{array}$ & 0.24 & 0.16 & 0.16 & 1.32 & 0.95 & $* \star$ & 2.4 \\
\hline C5d & $\begin{array}{l}\text { CD40 receptor associated factor } 1 \\
\quad(\text { CRAF } 1)\end{array}$ & 0.53 & 1.11 & 1.98 & 8.84 & 11.80 & ** & 2.4 \\
\hline $\mathrm{D} 2 \mathrm{~b}$ & $\begin{array}{l}\text { Basic transcription factor } 44 \mathrm{kDa} \\
\text { subunit }\end{array}$ & 19.53 & 16.11 & 25.90 & 6.19 & 4.40 & $* *$ & 2.3 \\
\hline F3h & Nerve growth factor HBNF-1 & 1.57 & 2.92 & 4.64 & 0.66 & 0.81 & ** & 2.3 \\
\hline D6h & Nuclear factor NF90 & 41.78 & 38.40 & 18.80 & 5.58 & 3.41 & ** & 2.3 \\
\hline $\mathrm{D} 2 \mathrm{n}$ & $\begin{array}{l}\text { ZFMl protein alternatively spliced } \\
\text { product }\end{array}$ & 0.70 & 0.83 & 0.67 & 2.67 & 3.59 & $* \star$ & 2.2 \\
\hline $\mathrm{D} 2 \mathrm{a}$ & $\begin{array}{l}\text { CCAAT displacement protein cut } \\
\text { homolog alt splice } 1\end{array}$ & 4.42 & 1.41 & 2.21 & 0.83 & 0.43 & ** & 2.2 \\
\hline D41 & Homeobox protein (HOX-11) & 1.65 & 1.57 & 2.54 & 0.34 & 0.51 & ** & 2.1 \\
\hline $\mathrm{C} 3 \mathrm{~b}$ & Glutathione S-transferase pi & 1.51 & 0.57 & 0.53 & 8.34 & 2.55 & ** & 2.1 \\
\hline F5l & Interleukin-1 alpha precursor (pre IL-1) & 0.60 & 1.02 & 1.98 & 0.43 & 0.42 & ** & 2.0 \\
\hline Ald & c-kit protooncogene & 0.44 & 0.32 & 0.37 & 1.11 & 1.77 & ** & 2.0 \\
\hline $\mathrm{C} 3 \mathrm{i}$ & Fas ligand (FASL) & 0.98 & 1.35 & 2.44 & 0.37 & 0.52 & ** & 2.0 \\
\hline B4k & $\begin{array}{l}\text { Mutant lymphocyte-specific protein } \\
\text { tyrosine kinase (LCK) }\end{array}$ & 0.34 & 0.14 & 0.13 & 0.77 & 0.59 & ** & 2.0 \\
\hline $\mathrm{C} 2 \mathrm{k}$ & Retinoid X receptor beta ( $R X R$-beta) & 7.51 & 5.51 & 5.88 & 1.96 & 1.27 & ** & 2.0 \\
\hline F2l & Bone morphogenetic protein $2 a$ & 0.25 & 0.18 & 0.32 & 1.14 & 1.41 & * & 2.0 \\
\hline
\end{tabular}

HEK, HEK-293, human embryonic kidney cell line; wt, wild type; S, standard deviation.

${ }^{a}$ Relative to average expression level of all 588 genes.

decrement in wild-type CFTR cells. The opposite is the case in the 4 th quadrant for genes in the $300^{\circ}-$ $330^{\circ}$ range. We are careful to emphasize that without further information we cannot, a priori, know which specific angles are of potential therapeutic relevance.

\section{Discussion}

The data presented here clearly demonstrate that the cellular expression of either wild-type or $\triangle$ F508-CFTR has global genomic consequences, the nature of which depends on the mutational 
Table 3. Candidate surrogate endpoint genes responding ${ }^{a}$ to $\mathrm{CPX}$ as a function of either mutant or wild-type CFTR $^{b}$

\begin{tabular}{|c|c|c|c|c|c|c|c|}
\hline \multirow[b]{2}{*}{ Location on Blot } & \multirow[b]{2}{*}{ Name of Gene } & \multirow[b]{2}{*}{$\begin{array}{c}\text { Angle of } \\
\text { CPX } \\
\text { Vector }^{c}\end{array}$} & \multicolumn{5}{|c|}{ Expression Level ${ }^{c}$} \\
\hline & & & HEK & wt & $\Delta \mathbf{F}$ & $\begin{array}{l}\text { wt }+ \\
\text { CPX }\end{array}$ & $\begin{array}{r}\mathbf{C P X}+ \\
\mathbf{C P X}\end{array}$ \\
\hline \multicolumn{8}{|l|}{ 2nd quadrant genes } \\
\hline \multicolumn{8}{|c|}{ CPX predominantly affects $\Delta \mathrm{F}$} \\
\hline A31 & Retinoblastoma susceptibility & 90 & 1.04 & 0.40 & 0.41 & 0.45 & 1.38 \\
\hline A5n & p55CDC & 90 & 15.52 & 7.79 & 9.86 & 7.80 & 25.06 \\
\hline F7n & Beta-preprotachykinin & 90 & 0.59 & 0.76 & 0.34 & 0.73 & 0.72 \\
\hline C6i & DNA polymerase alpha-subunit & 105 & 0.75 & 2.18 & 1.31 & 1.50 & 3.56 \\
\hline \multicolumn{8}{|c|}{ CPX affects wt and $\Delta F$ oppositely } \\
\hline D4h & $\begin{array}{l}\text { Transcriptional enhancer factor (TEF1) } \\
\text { DNA }\end{array}$ & 120 & 0.57 & 0.53 & 0.82 & 0.40 & 1.48 \\
\hline $\mathrm{A} 4 \mathrm{~b}$ & APC & 120 & 2.28 & 1.89 & 3.17 & 0.86 & 9.30 \\
\hline A4c & Breast cancer susceptibility (BRCA2) & 135 & 0.43 & 0.57 & 1.22 & 0.41 & 1.73 \\
\hline A4a & $\begin{array}{l}\text { fgr protooncogene encoded p55-c-fgr } \\
\text { protein }\end{array}$ & 135 & 0.97 & 1.23 & 1.53 & 0.78 & 2.25 \\
\hline \multicolumn{8}{|c|}{ CPX predominantly affects wt } \\
\hline $\mathrm{D} 4 \mathrm{~g}$ & Transcription factor ETR 101 & 180 & 2.78 & 6.07 & 12.45 & 3.33 & 12.44 \\
\hline A5b & DP2 dimerization partner of E2F & 180 & 29.411 & 03.81 & 153.5 & 40.9 & 155.4 \\
\hline Alh & v-erbA related ear- 2 protein & 180 & 1.63 & 6.82 & 8.97 & 2.48 & 9.01 \\
\hline Elj & PDGF-alpha receptor & 180 & 1.98 & 2.43 & 0.88 & 0.75 & 0.86 \\
\hline D6i & $\begin{array}{l}\text { HOX Al homeodomain protein } \\
\text { (HOXA1) }\end{array}$ & 180 & 2.50 & 3.43 & 1.45 & 0.86 & 1.24 \\
\hline \multicolumn{8}{|c|}{ 4th quadrant genes } \\
\hline \multicolumn{8}{|c|}{ CPX predominantly affects $\Delta \mathrm{F}$} \\
\hline F6h & Interleukin-14 (IL-14) & 270 & 2.12 & 5.67 & 3.92 & 6.00 & 1.98 \\
\hline F6g & Interleukin-13 (IL-13) & 285 & 40.68 & 73.34 & 84.72 & 84.11 & 35.14 \\
\hline \multicolumn{8}{|c|}{ CPX affects wt and $\Delta \mathrm{F}$ oppositely } \\
\hline A7l & $C-1$ & 330 & 1.59 & 1.65 & 3.77 & 2.34 & 3.18 \\
\hline \multicolumn{8}{|c|}{ CPX predominantly affects wt } \\
\hline E6g & Contactin 1 precursor (CNTN1) & 345 & 1.56 & 0.71 & 0.71 & 1.52 & 0.62 \\
\hline $\mathrm{D} 2 \mathrm{f}$ & DNA-binding protein TAXREB67 & 360 & 1.48 & 1.43 & 1.52 & 4.04 & 1.65 \\
\hline
\end{tabular}

${ }^{a}$ Relative to average expression level of all 588 genes.

${ }^{b}$ Genes having differences $\geq 2$ SD from any of the respective means.

${ }^{c}$ All these CPX genomic vectors are within 1 SD from the average vector length.

wt, wild type; HEK, HEK-293, human embryonic kidney cell line.

status of the CFTR gene. This is a remarkable and somewhat unexpected finding in view of the implicit assumption that gene transfer, as might occur in gene therapy of the wild-type CFTR gene, ought only to have the consequence of increasing the level of functional CFTR protein in the target cell. Instead, we find here that many changes occur, including several which are mu- tation dependent. However, the significance of individual changes in gene expression will only be discerned as we employ ever-larger genome arrays, and especially as we query additional $\mathrm{CF}$ cells and tissues.

A further exceptional finding is that administration of the CF drug CPX has mutation-dependent and mutation-independent conse- 
quences for global gene expression. Using our novel approach of genomic drug vectors, we have been able to seive out a group of 69 genes ( $12 \%$ of the total), which, in the presence of CPX, are induced to move significantly and differentially depending on the mutational status of CFTR. In the absence of more biological information we cannot discern which directions are better or worse, since any of these may have positive or negative effects on the physiology of the CF cell. The list in Table 3 is a subgroup of those 69 genes selected on the basis of having a difference of $>2$ SDs from any one of the respective means. We note that this list overlaps only occasionally with those genes known on the basis of the present study to be associated with expression of mutant or wild-type CFTR alone (cf. Table 1). In the future, when more data on the physiological sequellae of overexpression or underexpression of each gene become available, it may become possible to use this approach to predict the consequences of different potential drug or gene therapies. It might even be possible to do this on an individual patient basis.

It is perhaps not so unexpected that CPX might also induce changes in expression of certain genes in a mutationally independent manner. However, the magnitude of some of these changes, ranging up to 6 SDs, is truly exceptional. In this category we find two PKA regulatory subunits and one tyrosine kinase. In principal, the induction of these genes by CPX might be important for CF. For example, PKA is necessary to activate CFTR channels. However, tyrosine kinases can also activate CFTR channels independently of PKA (results from many investigators summarized in ref. 51). On the other hand, it is also possible that some consequences of mutation-independent CPX action could be due to drug action on classical adenosine receptors. However, the parental HEK293 cells have only low levels of $A_{1}$ receptors (52), and CPX is widely reported to have antiproliferative effects on those epithelial and other cell types where the $A_{1}$ receptors do occur (53-55). Therefore, discerning whether these CPX-dependent effects are therapeutically wanted or unwanted in terms of repair of specific CFTR functions will require much further study.

Another interesting aspect of these results is that of those genes shown by our present work to be significantly changed by CFTR mutation or by CPX, surprisingly few have been historically associated with CF. The Atlas microarray is far from complete with regard to CF. However, it does contain at least 25 genes that have been thought at one time or another to be associated with $C F$, and we thought it would be of interest to summarize the data for them in Table 4. Indeed, most of these genes are not affected by the mutation, except for HSP70, which is reduced, and mucl 8 (a mucin) and IL10, which are increased. By contrast, in the presence of CPX, many of these genes are increased. The most profound among these include PKA regulatory subunits; the tyrosine kinase JAKl; AXL tyrosine kinase; a panepithelial glycoprotein; HSP60, HSP70, and HSP86; MUC18; caspase9; IL6; and, marginally, the $A_{1}$-adenosine receptor. Presumably, with further study of larger arrays and under different conditions, it will be possible to identify a more complete set of CF-relevant reporter genes, and to construct a CF chip or blot suitable for $\mathrm{CF}$ drug discovery. Since we are presently analyzing only 588 of the 100,000 potential genes in the human genome, we can extrapolate by proportion that there could be as many as $5000 \mathrm{CF}$-relevant genes.

One advantage of the GRASP approach to accurate data seiving is that the intrinsic high number of genes in each blot can be employed in concert to profoundly raise the statistical strength of the analysis. On the basis of our own analysis of the ATLAS system in this series of experiments (see Materials and Methods for statistics), data from individual cDNA targets could just as easily been used. However, the problem with this simple approach is that the number of genes that are observed to change expression in a mutation- or drug-dependent manner becomes very large. Then, to determine whether a specific change, no matter how large or small, is truly significant, a large number of experiments must be performed. Given the current cost of an individual blot, this ceases to be a viable option. However, by asking, instead, whether any specific change is greater than the SD calculated for the entire sample, we take into account the entire sample when deciding on the significance of the specific change. This is the basis of the GRASP genome seiving technique.

There is also an additional advantage to presenting the expression data as a ratio to the same gene expressed in the parental cell line. The parental cell line in the denominator is genetically very similar to the cells in the numerator, except for the transfected CFTR gene. The parental cell thereby provides a biologically relevant normalization factor. We might point out here that such a specific comparison is intrinsically difficult to 
Table 4. Effects of CFTR mutation and CPX on expression of available CF-relevant genes

\begin{tabular}{|c|c|c|c|c|c|c|c|c|}
\hline \multirow[b]{2}{*}{ Location } & \multirow[b]{2}{*}{ Name of Gene } & \multicolumn{5}{|c|}{ Expression Level $^{a}$} & \multicolumn{2}{|c|}{ CPX Vector } \\
\hline & & HEK & wt & $\Delta \mathbf{F}$ & $\begin{array}{l}\text { wt }+ \\
\text { CPX }\end{array}$ & $\begin{array}{l}\mathbf{A F}+ \\
\mathbf{C P X}\end{array}$ & $\begin{array}{l}\text { Length } \\
(\mathrm{S})^{b}\end{array}$ & Angle \\
\hline \multicolumn{9}{|c|}{ Kinases and phosphatases } \\
\hline B51 & Protein-tyrosine kinase (JAKl) & 0.39 & 0.19 & 0.19 & 10.42 & 8.20 & 2.7 & 45 \\
\hline B7f & Tyrosine kinase (Tnkl) & 1.56 & 1.27 & 1.49 & 1.02 & 0.98 & -0.3 & 240 \\
\hline $\mathrm{B} 2 \mathrm{i}$ & Protein kinase $C \delta$-type & 1.18 & 0.70 & 0.49 & 0.68 & 0.51 & -3.0 & 135 \\
\hline $\mathrm{B} 5 \mathrm{j}$ & Protein kinase $C(\mathrm{PKC})$ type $\beta \mathrm{I}$ & 0.32 & 0.16 & 0.17 & 0.56 & 0.44 & 1.1 & 30 \\
\hline B5k & PKA subunit RII- $\beta$ & 0.24 & 0.16 & 0.16 & 1.32 & 0.95 & 1.8 & 45 \\
\hline B5m & PKA regulatory subunit RI- $\beta$ & 5.78 & 2.44 & 2.56 & 203.33 & 234.82 & 2.8 & 45 \\
\hline B6b & PKA catalytic subunit type $\alpha$ & 3.39 & 5.94 & 6.25 & 2.78 & 2.95 & 0.7 & 225 \\
\hline B7g & Protein tyrosine phosphatase (CIP2) & 0.26 & 0.24 & 0.23 & 0.35 & 0.27 & -0.5 & 30 \\
\hline A5c & AXL tyrosine kinase receptor & 1.52 & 4.16 & 14.67 & 1.54 & 7.18 & 0.8 & 210 \\
\hline B6n & $\begin{array}{l}\text { Receptor tyrosine kinase ligand } \\
\text { (LERK-3) }\end{array}$ & 0.30 & 0.12 & 0.12 & 2.40 & 1.65 & 2.3 & 45 \\
\hline \multicolumn{9}{|c|}{ Heat shock proteins } \\
\hline B7l & Heat shock protein HSP27 & 1.83 & 1.56 & 1.19 & 4.50 & 2.39 & 0.9 & 30 \\
\hline B7i & Heat-shock protein 40 & 1.55 & 1.56 & 1.53 & 1.45 & 1.15 & -0.9 & 255 \\
\hline B7j & Chaperonin (HSP60) & 0.64 & 0.47 & 0.47 & 1.06 & 1.11 & 0.8 & 45 \\
\hline $\mathrm{B} 7 \mathrm{~m}$ & Heat shock protein (HSP 70) & 0.47 & 0.37 & 0.16 & 0.81 & 0.52 & 1.0 & 60 \\
\hline B7k & Heat shock protein hsp86 & 0.31 & 0.17 & 0.19 & 1.76 & 2.41 & 2.1 & 45 \\
\hline \multicolumn{9}{|c|}{ Adenosine receptors } \\
\hline $\mathrm{Clh}$ & A2a adenosine receptor & 0.53 & 0.68 & 0.53 & 0.55 & 0.43 & -0.9 & 225 \\
\hline $\mathrm{Cli}$ & Al adenosine receptor & 3.01 & 3.22 & 2.27 & 2.17 & 1.06 & 0.4 & 240 \\
\hline $\mathrm{Clj}$ & A3 adenosine receptor & 0.56 & 0.47 & 0.37 & 0.71 & 0.50 & -0.3 & 30 \\
\hline \multicolumn{9}{|c|}{ Inflammatory } \\
\hline $\mathrm{F} 2 \mathrm{j}$ & RANTES pro-inflammatory cytokine & 9.30 & 32.49 & 45.30 & 23.54 & 51.80 & -0.7 & 150 \\
\hline F6b & Interleukin-6 (IL-6) precursor & 1.19 & 0.39 & 0.43 & 5.73 & 3.07 & 2.0 & 30 \\
\hline F6f & Interleukin-10 (IL-10) & 4.16 & 4.64 & 7.42 & 5.02 & 2.59 & 0.6 & 270 \\
\hline \multicolumn{9}{|c|}{ Transcription factors } \\
\hline D2g & $\begin{array}{l}\text { cAMP-responsive element-binding } \\
\text { protein }\end{array}$ & 1.17 & 1.28 & 1.10 & 0.70 & 0.67 & 0.3 & 225 \\
\hline B3a & NF $\kappa \mathrm{B}$ transcription factor p65 subunit & 0.56 & 0.39 & 0.33 & 0.79 & 0.62 & 0.5 & 45 \\
\hline \multicolumn{9}{|c|}{ Miscellaneous } \\
\hline A5i & MUC18 glycoprotein & 0.59 & 0.27 & 0.50 & 0.45 & 1.17 & 0.6 & 60 \\
\hline $\mathrm{C} 4 \mathrm{l}$ & Caspase-9 precursor & 1.50 & 1.07 & 1.27 & 8.36 & 4.76 & 1.7 & 30 \\
\hline
\end{tabular}

HEK, HEK-293, human embryonic kidney cell line; wt, wild type; S, standard deviation.

${ }^{a}$ Relative to average expression level.

${ }^{b}$ Length of vector expressed as number of $S$ above (positive) or below (negative) the average length.

realize with human tissue samples because there is usually no "parental" cell population available for analysis.

Finally, from a drug development vantage point, another important advantage to the
GRASP approach is that the genomic vector approach yields a radial distribution useful for discerning changes that are specific either to the drug or to the mutation. This approach emphasizes movements directed toward or away from 
the wild-type expression phenotype. These types of vectors, when taken as a group, thus constitute a quantitative, dynamic form of cluster analysis (56) that has substantial advantages for mining genomic data. We therefore believe that this type of analysis may prove to be of fundamental importance for the development of surrogate endpoints for drug discovery, not only in CF but for other genetic diseases as well.

\section{Acknowledgments}

The authors thank Dr. A. Namboodiri, Dr. S. Galdwicky, Dr. L. Fossom, Dr. X. Leighton, and Ms. M. Glasman for substantive help and discussions, and acknowledge financial support from the NIH (RO1-DK53051), the Cystic Fibrosis Foundation, and the Juvenile Diabetes Foundation, International.

\section{References}

1. Bailey DS, Bondar A, Furness LM. (1998) Pharmacogenomics-it's not just pharmacogenetics. Curr. Opin. Biotechnol. 6: 595-601.

2. Ferrari P. (1998) Pharmacogenomics: a new approach to individual therapy of hypertension? Curr. Opin. Nephrol. Hypertens. 7: 217-221.

3. Graever G, Shoemaker DD, Jones TW, et al. (1999) Genomic profiling of drug sensitivities via induced haploinsufficiency. Nat. Genet. 3: 278283.

4. Welsh MJ, Tsui L-C, Boat TF, Beaudet AL. (1995) Cystic fibrosis. In: Scriver CL, Sly WS, Valle D (eds). The Metabolic and Molecular Bases of Inherited Diseases, 7th ed. McGraw-Hill, New York, pp. 3799-3876.

5. Collins FS. (1992) Cystic fibrosis molecular biology and therapeutic implications. Science 256: 774-779.

6. Drumm ML, Pope HA, Cliff WH, et al. (1990) Correction of the cystic fibrosis defect in vitro by retrovirus-mediated gene transfer. Cell 62: 12271233.

7. Rubenstein RC, Egan ME, Zeitlin PL. (1997) In vitro pharmacologic restoration of CFTR-mediated chloride transport in sodium 4-phenylbutyrate in cystic fibrosis epithelial cells containing delta F508-CFTR. J. Clin. Invest. 100: 2457-2465.

8. Pollard HB. (1997) Role of CPX in promoting trafficking and chloride channel activity of wildtype and mutant CFTR. Pediatr. Pulmonol. S14: 128131.

9. Riordan JR, Rommens JM, Karem B-S, et al. (1989) Identification of the cystic fibrosis gene: Cloning and characterization of complementary DNA. Science 245: 1066-1073.
10. Rommens JM, Iannuzzi MC, Karem B-S, et al. (1989) Identification of the cystic fibrosis gene: chromosome walking and jumping. Science 245: 1059-1065.

11. Karem B-S, Rommens JM, Buchanan JA, et al. (1989) Identification of the cystic fibrosis gene: genetic analysis. Science 245: 1073-1080.

12. Tsui L-C. (1992) Mutations and sequence variations detected in the cystic fibrosis transmembrane conductance regulator (CFTR) gene: a report from the cystic fibrosis genetic analysis consortium. Hum. Mutat. 1: 197-203.

13. Tsui L-C. (1992) The spectrum of cystic fibrosis mutations. Trends Genet. 8: 392-398.

14. Schultz BD, Singh AK, Devor DC, Bridges RJ. (1999) Pharmacology of CFTR chloride channel activity. Physiol. Rev. 79: S109-S144.

15. Eidelman O, Guay-Broder C, van Galen PJM, et al. (1992) Al-adenosine antagonists activate chloride efflux from cystic fibrosis cells. Proc. Natl. Acad. Sci. (U.S.A.) 89: 5562-5566.

16. Schweibert E, Gruenert D, Stanton B. (1992) Gproteins inhibit cAMP-activated chloride channels in normal and CF epithelia. Pediatr. Pulmonol. S8: 257.

17. Guay-Broder C, Jacobson KA, BarNoy $S$, et al. (1995) Al-receptor antagonist 8 cyclopentyl-1,3dipropyl-xanthine (CPX) selectively activates chloride efflux from human epithelial and mouse fibroblast cell lines expressing the CFTR( $\Delta$ F508) mutation, but not the wild type CFTR. Biochemistry 34: 9079-9087.

18. Jacobson KA, Guay-Broder C, van Galen PJM et al. (1995) Stimulation of alkylxanthines of chloride efflux from CFPAC-1 cells does not involve Al-adenosine receptors. Biochemistry 34: 90889094.

19. Casavola V, Turner RJ, Guay-Broder C, Jacobson KA, Eidelman O, Pollard HB. (1995) CPX, a selective $\mathrm{Al}$ adenosine receptor antagonist, regulates intracellular $\mathrm{pH}$ in cystic fibrosis cells. Am. J. Physiol. (Cell) 269: C226-233.

20. Haws CM, Nepomuceno I, Krouse ME, et al. (1996) $\triangle$ F508-CFTR channels: kinetics, activation by forskolin, and potentiation by xanthines. Am. J. Physiol. 270: 1544-1555.

21. Arispe N, Ma J, Jacobson KA, Pollard HB. (1998) Direct activation of cystic fibrosis transmembrane conductance regulator by 8-cyclopentyl-1,3dipropylxanthine and 1,3-diallyl-8-cyclohexylxanthine. J. Biol. Chem. 273: 5724-5734.

22. Cheng SH, Gregory RJ, Marshall J, et al. (1990) Defective intracellular transport and processing of CFTR is the molecular basis of most cystic fibrosis. Cell 63: 827-834.

23. Cohen BE, Lee G, Jacobson KA, et al. (1997) CPX (1,3-dipropyl-8-cyclopentyl xanthine) and other alkyl-xanthines differentially bind to the wild type and $\Delta$ F508 mutant first nucleotide binding fold (NBF-1) domains of the cystic fibrosis transmem- 
brane conductance regulator (CFTR). Biochemistry 36: 6455-6461.

24. Stutts MJ, Canessa CM, Olsen JC, et al. (1995) CFTR as a cAMP-dependent regulator of sodium channels. Science 269: 847-850.

25. Ismailov II, Awayda MS, Jovov B, et al. (1996) Regulation of epithelial sodium channels by the cystic fibrosis transmembrane conductance regulator. J. Biol. Chem. 271: 4725-4732.

26. Schweibert EM, Benos DJ, Egan ME, Stutts MJ, Guggino WB. (1999) CFTR is a conductance regulator as well as a chloride channel. Physiol. Rev. 79: S145-S166.

27. Jacobson KA. (1988) Adenosine A3 receptors: novel ligands and paradoxical effects. Trends Pharmacol. Sci. 19: 184-191.

28. Fulmer SB, Schweibert EM, Morales MM, Guggino WB, Cutting GR. (1995) Two cystic fibrosis transmembrane conductance regulator mutations have different effects on both pulmonary phenotype and regulation of outwardly rectified chloride currents. Proc. Natl. Acad. Sci. U.S.A. 92: 68326836.

29. Neglia JP, FitzSimmons SC, Maisonneuve $P$, et al. (1995) The risk of cancer among patients with cystic fibrosis. Cystic Fibrosis and Cancer Study Group. N. Engl. J. Med. 332: 494-499.

30. Sheldon CD, Hodson ME, Carpenter LM, Swerdlow AJ. (1993) A cohort study of cystic fibrosis and malignancy. Br. J. Cancer 68: 1025-1028.

31. Chaun H, Paty B, Nakiela EM, Schmidt N, Holden JK, Melosky B. (1996) Colonic carcinoma in two adult cystic fibrosis patients. Can. J. Gastroenterol. 10: $440-442$.

32. Neugut AI, Jacobson JS, Suh S, Mukherjee $R$, Arber N. (1998) The epidemiology of cancer of the small bowel. Cancer Epidemiol. Biomark. Prev. 7: 243-251.

33. Tsogalis GJ, Faber G, Dalldorf FG, Friedman KJ, Silverman LM, Yankaskas JR. (1994) Association of pancreatic adenocarcinoma, mild lung disease, and delta F508 mutation in a cystic fibrosis patient. Clin. Chem. 40: 1972-1974.

34. Garcia FU, Galindo LM, Holsclaw DS, Jr. (1998) Breast abnormalities in patients with cystic fibrosis: previously unrecognised changes. Ann. Diagn. Pathol. 2: 281-285.

35. Southey MC, Batten L, Anderson CR, et al. (1998) CFTR deltaF508 carrier status, risk of breast cancer before the age of $\mathbf{4 0}$ and histological grading in a population-based case-control study. Int. J. Cancer 79: 487-489.

36. Padua RA, Warren N, Grimshaw D, et al. (1997) The cystic fibrosis delta F508 mutation and cancer. Hum. Mutat. 10: 45-48.

37. Gress TM, Muller-Pillasch F, Geng M, et al. (1996) A pancreatic cancer-specific expression profile. Oncogene 13: 1819-1830.

38. Heller RA, Schena M, Chai A, et al. (1997) Discovery and analysis of inflammatory disease-re- lated genes using cDNA microarrays. Proc. Natl. Acad. Sci. U.S.A. 94: 2150-2155.

39. Pappalardo PA, Bonner R, Krizman DB, EmmertBuck MR, Liotta LA. (1998) Microdissection, microchip arrays, and molecular analysis of tumor cells (primary and metastases). Semin. Radiat. Oncol. 8: 217-223.

40. Pietu G, Alibert O, Guichard V, et al. (1996) Novel gene transcripts preferentially expressed in human muscles revealed by quantitative hybridization of a high density cDNA array. Genome Res. 6: 492-503.

41. Schena M, Shalon D, Heller R, Chai A, Brown PO, Davis RW. (1996) Parallel human genome analysis: microarray-based expression monitoring of 1000 genes. Proc. Natl. Acad. Sci. U.S.A. 93: 1061410619.

42. Welford SM, Gregg J, Chen E, et al. (1998) Detection of differentially expressed genes in primary tumor tissues using representational differences analysis coupled to microarray hybridization. Nucl. Acids Res. 26: 3059-3065.

43. Lipshutz RJ, Fodor SP, Gingeras TR, Lockhart DJ. (1999) High density synthetic oligonucleotide arrays. Nat. Genet. 21 (1 Suppl): 20-24.

44. Watson SJ, Akil H. (1999) Gene chips and arrays revealed: a primer on the power and their uses. Biol. Psychiatry 45: 533-543.

45. Alizadeh A, Eisen M, Botstein D, Brown PO, Staudt LM. (1998) Probing lymphocyte biology by genome-scale gene expression analysis. J. Clin. Immunol. 18: 373-379.

46. DeRisi J, Penland L, Brown PO, et al. (1996) Use of a cDNA microarray to analyse gene expression patterns in human cancer. Nat. Genet. 14: 367370.

47. Ollila J, Vihinen M. (1998) Stimulation of B and T cells activates expression of transcription and differentiation factors. Biochem. Biophys. Res. Commun. 249: 475-480.

48. Shim C, Zhang W, Rhee CH, Lee JH. (1998) Profiling of differentially expressed genes in human primary cervical cancer by complementary DNA expression array. Clin. Cancer Res. 4: 3045-3050.

49. Tao T, Xie J, Drumm ML, Zhao J, Davis PB, Ma J. (1996) Slow conversions among subconductance states of cystic fibrosis transmembrane conductance regulator chloride channel. Biophys. J. 70: 743-753.

50. Chirgwin JM, Przybyla AE, MacDonald RJ, Rutter WJ. (1979) Isolation of biologically active ribonucleic acid from sources enriched in ribonuclease. Biochemistry 18: 5294-5299.

51. Gadsby DC, Nairn AC. (1999) Control of CFTR channel gating by phosphorylation and nucleotide hydrolysis. Physiol. Rev. 79: S77-S107.

52. Gao Z, Chen T, Weber MJ, Linden J. (1999) $\mathrm{A}_{\mathrm{aBB}}$ adenosine and $\mathrm{P}_{2} \mathrm{Y}_{2}$ receptors stimulate mitogen-activated protein kinase in human embry- 
onic kidney-293 cells. J. Med. Chem. 274: 59725980.

53. Shimegi S. (1998) Mitogenic action of adenosine on osteoblast-like cells, MC3T3-E1. Calcif. Tissue Int. 62: 418-425.

54. Yuh IS, Sheffield LG. (1998) Adenosine stimulation of DNA synthesis in mammary epithelial cells. Proc. Soc. Exp. Biol. Med. 218: 341-348.
55. Lelievre V, Muller JM, Falcon J. (1998) Adenosine modulates cell proliferation in human colonic adenocarcinoma. I. Possible involvement of Al receptor subtypes in HT29 cells. Eur. J. Pharmacol. 341: 289-297.

56. Bassett DE Jr, Eisen MB, Boguski MS. (1999) Gene expression informatics-it's all in your mine. Nat. Genet. Suppl. 21: 51-55. 